\title{
Talaporfin Sodium
}

National Cancer Institute

\section{Source}

National Cancer Institute. Talaporfin Sodium. NCI Thesaurus. Code C26675.

An agent consisting of chlorin e6, derived from chlorophyll, and L-aspartic acid with photosensitizing activity. After intratumoral activation by light emitting diodes, taporfin sodium forms an extended high energy conformational state that generates sing let oxygen, resulting in free radical-mediated cell death. (NCI04) 